Beata Edyta Dworakowska

Biatystok

\title{
Reprodukcja jako jeden ze sposobów na osiągniecie ekwiwalencji formalno-estetycznej w przekładzie (na materiale wierszy księdza Jana Twardowskiego)
}

Słowa kluczowe: poezja księdza Jana Twardowskiego, przekład, ekwiwalencja formalno-estetyczna

„Poezja przestała być dziś dla nas sztuką robienia wierszy, stała się szczególnym sposobem użycia języka" [Jarosiński 1985, 174]. Każdy najdrobniejszy element języka może w poezji stać się elementem znaczącym, elementy formalne moga przybierać charakter semantyczny, uzyskując dodatkowe znaczenia. Styl poszczególnych utworów jest konstruowany poprzez zastosowanie różnorodnych środków stylowych. B. Wyderka wyszczególnia wśród nich: środki organizacji warstwy brzmieniowej, kategorie fleksyjne, formy słowotwórcze, leksykalne środki stylowe, figury, tropy, środki składniowe, jednostki struktury tekstu oraz pozajęzykowe środki ekspresji [zob. Wyderka 1995, 53-81]. Najważniejszym czynnikiem decydującym o kształcie wiersza jest słowo. Formy poetyckie odzwierciedlają prawidłowości użycia języka. Łatwo się o tym przekonać, rozpatrując różnojęzyczne utwory poetyckie w kontekście ich językowych systemów [zob. Pszczołowska 2002]. Wiersz posiada dwa naturalne układy odniesień: pierwszym jest struktura językowa, drugim - struktura literacka. Konfrontacja sposobów kształtowania wiersza odbywa się pośrednio poprzez konfrontację systemów językowych [zob. Baluch 2007].

Dzieła literackie pełnią szereg istotnych funkcji, które bywają rozmaicie systematyzowane. Sa to m.in.: funkcja filozoficzno-społeczna, estetyczna, poznawcza, emocjonalna, wychowawcza, werystyczna, rozrywkowa, substytutywna [zob. Wojciechowski 1999, 100]. Oprócz wymienionych, ważną rolę 
odgrywają także: funkcja ekspresywna, poznawcza, wychowawcza, komunikatywna, prezentacyjna, impresywna i inne. Nie ma tekstów, które pełniłyby tylko jedną funkcję. W tekstach poetyckich niewątpliwie nadrzędna jest funkcja estetyczna (poetycka, autoteliczna), której realizacji służy selekcja elementów świata przedstawionego, doskonałość formy, artystyczna kompozycja i dobór środków językowo-stylistycznych. Funkcja ta polega na dostarczaniu odbiorcy wrażeń estetycznych, przekazywaniu wartości artystycznych. Jest nastawiona na komunikat. Przeżycie estetyczne sięga głębokich warstw osobowości, rozbudza wyobraźnię i wrażliwość. Ma być ono reakcją uczuciową, która nie wykracza poza swój bodziec przedmiotowy, skupiającą się na nim całkowicie. Przeżycia te mają charakter kontemplacyjny - obezwładniają swoim pięknem, lub czynny - są równocześnie elementem wyobraźni odbiorcy. Poezja zaspokaja w czytelniku potrzebę wzruszeń estetycznych i refleksji moralnej. Jej rolą jest przedstawienie tekstu w sposób oryginalny, unikatowy. Funkcja poetycka dominuje w tekście nastawionym na przekaz. Każdy utwór literacki zawiera obraz literacki, kształtowany pośrednio przez warstwę znaków językowych i ich znaczeń, bowiem świat przedstawiony dzieła jest tworem semantycznym. Poezja wykorzystuje środki artystycznego przekazu, celową eliptyczność itp.

Funkcja poetycka dochodzi do głosu, gdy wypowiedź odbiega od neutralnego toku. W zwykłej komunikacji znak językowy jest transparentny. Skupiamy uwagę na jego treści, a nie na formie. Realizując funkcję estetyczną, koncentrujemy się na tym, o czym mowa, a nie na tym, co zostało formalnie wyrażone. Następuje zachwianie transparencji znaku językowego. Funkcja autoteliczna dąży do odświeżenia języka, przełamania szablonu. Wówczas każdy element tekstu jest równie ważny. Każda najdrobniejsza zmiana może naruszać wartość artystyczną komunikatu. Z funkcją estetyczną ściśle związana jest funkcja ekspresywna (emotywna). Polega ona na ujawnianiu przeżyć podmiotu mówiącego i jego stosunku do świata przedstawionego. Dominuje w tekstach nastawionych na wyrażanie uczuć, emocji, stanów wewnętrznych nadawcy. Realizowana jest przez środki stylistyczne, m.in.: epitety, metafory, porównania, wyrazy ekspresywne, nacechowane emocjonalnie [zob. Śliwińska 2009, 273]. Spełnia się przez przeżywanie emocji, które jest sprawą osobistą, indywidualną dla każdego czytelnika, zależną od jego wrażliwości.

Niemal każdą wypowiedź językową można badać z punktu widzenia jej wartości ekspresywnej. Zarówno pisarz, jak i tłumacz, mają wielkie możliwości wydobywania ze słowa przez zestawienie go z innymi słowami jego znaczeń utajonych bądź tworzenia znaczeń całkiem nowych. „Poeta posługuje się językiem w szczególny sposób, stosuje chwyty, które wytrącają jed- 
nostki leksykalne z automatyzmu mowy nieartystycznej i tym samym zmuszają odbiorcę do przeżycia znaków jako elementów nowej, nieznanej gry" [Pajdzińska 1993, 15]. Takie różnorodne zestawienia tworzące nowe sensy nazywa się tropami. Stanowią one integralny składnik stylu, ich wartość nie tkwi w nich samych, ale ujawnia się w kontekście. Wartość ta jest relatywna, ponieważ uzależniona jest od roli, jaką pełnią tropy w określonym tekście [por. Głowiński, Okopień-Sławińska, Sławiński 1967]. Pierwotnie trop oznaczał przenośne użycie wyrazu. Obecnie za trop uważa się wyraz lub wyrażenie użyte $\mathrm{w}$ innym znaczeniu lub kontekście niż obligatoryjnie przyjęte w języku. Zdaniem A. Kulawika: „Tropy stylistyczne są to ustalone sposoby organizowania semantyki wypowiedzi, sposoby łączenia poszczególnych wyrazów w większe całostki semantyczne na poziomie wyrażenia, członu syntaktycznego lub nawet zdania. (...) Rozumiemy zatem trop jako zabieg szczególnej intensyfikacji kontekstu, intensyfikacji napięć pomiędzy zakresami znaczeniowymi słów" [Kulawik 1997, 91-92]. Środki stylistyczne są elementem wyróżniającym tekst artystyczny spośród pozostałych typów tekstów. Mają na celu wywołanie u odbiorcy pożądanych emocji. Dla poety są one atrakcyjnym, dającym się wielorako sfunkcjonalizować, materiałem twórczym.

Każdy poeta posługuje się kodem językowym w sobie właściwy sposób. W indywidualnym stylu pisarza realizuje się zarówno swoiste wykorzystywanie środków językowych w nowych funkcjach, ich dobór zgodny z lingwistycznym smakiem autora, jak własny system kombinacji różnych środków stylistycznych czy też tendencja do stosowania określonych obrazów i sposobów ich konstruowania. Poezja Jana Twardowskiego wpisuje się naturalnie w rytm liryki religijnej, opartej na tematyce sacrum. Liryka religijna bywa intymnym przeżyciem uczuć religijnych, wyrazem tęsknoty człowieka do transcendencji, refleksją nad sensem życia i śmierci. Jan Twardowski, tworząc poezję religijną, poświęca ją swemu indywidualnemu przeżyciu Boga. Wyraża wiarę w sposób „niezinstytucjonalizowany” [zob. Kulawik 1997, 301]. Styl poety ma na celu m.in. zarysowanie pewnej atmosfery emocjonalnej, przybliżenie czytelnikowi sfery religijnej poprzez tropy stylistyczne, podkreślające wartości egzystencjalne i eschatologiczne oraz konstruowanie obrazów nacechowanych emocjonalnie. Twardowski wyrażał emocje proste i nieskomplikowane, jednocześnie podkreślając ich intymność. W ramach jednego wersu zestawiał słowa, wywodzące się z różnych rejestrów stylistycznych, przez co uzyskiwał zaskakujące efekty poetyckie, polegające na stworzeniu nowatorskiego języka wiary. „Poeta nie tylko korzystał ze »słownictwa wspólnoodmianowego «, bardzo ciekawe efekty uzyskiwał, sięgając po leksykę z rejestru emocjonalnego i swobodnego" [Ciesielska 2009, 25]. 
Wykorzystywał on środki właściwe liryce, zestawiając w nich słowa w sobie tylko właściwy sposób. Autor nie stronił od obrazowych metafor, paradoksów czy też odwołań do stereotypowych sformułowań, co jednak nie powodowało spłycenia tematyki sacrum. Dla wierszy Twardowskiego charakterystyczne jest „pochylenie się nad słowem, docieranie do ukrytego bogactwa jego znaczeń, wykorzystywanie go do różnych gier językowych, ukazywanie w języku poetyckim paradoksów rzeczywistości, operowanie aforyzmem, uogólniającą, często szokującą puentą" [Puzynina 2007, 28)]. Język artystyczny Jana Twardowskiego jest nacechowany paradoksami, zestawieniami, sytuacjami poetyckimi, dyskretną metaforyką [zob. Sochoń 2007, 41]. Analizując styl utworów księdza Jana, E. Ciesielska konstatuje: „Z pewnością jedną z podstawowych cech omawianej poezji jest ekspresywność. (...) liryki księdza Jana to słowa starannie dobrane, świadomie użyte, nieprzypadkowe. Nacechowane potocznie i ekspresywnie leksemy i połączenia wyrazowe, celowo stosowane przez poetę, pełnią zatem określoną funkcję, m.in. zaskoczenia odbiorcy niecodziennym zestawieniem słów, odświeżenia sposobu mówienia o Bogu i sprawach ducha" [Ciesielska 2009, 59-60]. W wierszach poety pojawiają się epitety, porównania, metafory, animizacje, personifikacje, oksymorony, peryfrazy, nazwy ekspresywne i inne środki artystycznego wyrazu. Podczas lektury poezji Twardowskiego trzeba uważać, aby w rzeczach zwyczajnych nie przeoczyć głębszego znaczenia.

Te ogólne uwagi wskazują na ogrom problemów, przed jakimi stanęli tłumacze poezji Jana Twardowskiego. Trudność przekładu poezji jest rzeczą oczywistą i niezaprzeczalną. Tłumacz, podobnie jak autor oryginału, tworząc tekst ma możliwość wyboru. Z zasobów języka przekładu czerpie te słowa, formy, konstrukcje, które odpowiadają jego strategii. Zasadniczym zadaniem, jakie wypływa z założonego tematu, jest analiza tekstów wierszy poety i ich rosyjskich przekładów [zob. Źródła] pod kątem ekwiwalencji formalno-estetycznej. Rolą tłumacza poezji jest rekonstrukcja modelu świata zawartego w tekście wyjściowym i przeniesienie go w materię innego języka. Nie istnieje jednak jeden wymiar, w którym oczekujemy translacji. Zagadnienie ekwiwalencji przekładowej stanowi dominantę konfrontacji przekładowej. Ekwiwalencja pojmowana w sposób wąski oznacza równoważność semantyczną między tekstem wyjściowym a tekstem docelowym [zob. Dąmbska-Prokop 2000, 68], zaś w sposób szeroki - istnienie pewnej relacji między tekstami, niezależnie od relacji, które istnieją między dwoma językami [por. Toury 1995]. Nie dotyczy ona tylko poziomu językowego, ale i „sytuacji”, która wymaga zastosowania różnych środków stylistycznych. W literaturze przedmiotu można spotkać różne typologie ekwiwalencji. Problemem tym zajmowało się wielu badaczy. E. Nida i C. Taber wyróżnili ekwi- 
walencję formalną, zorientowaną na treść i formę tekstu wyjściowego oraz dynamiczną, ukierunkowaną na tekst przekładu [zob. Nida, Taber, 1969]. G. Jäger zaprezentował podział na ekwiwalencję komunikacyjną, opartą na porównaniu wartości komunikacyjnej tekstów oryginału i przekładu, i funkcjonalną, zorientowaną na porównanie wartości funkcjonalnych, znaczeń językowych obu tekstów [zob. Jäger 1982]. W. Koller starał się uporządkować pojęcie ekwiwalencji globalnej tekstu. Stwierdza on, że każdy przekład niesie z sobą wyzwanie dla nowego przekładu [Koller 1995, 203]. Zdaniem tego autora, aby można było mówić o ekwiwalentności tekstu, trzeba wziąć pod uwage pięć kategorii: ekwiwalencja denotatywna, konotatywna, tekstowo-normatywna, pragmatyczna, formalno-estetyczna [zob. Koller 1983, 187; Pisarska, Tomaszkiewicz 1996, 170]. Wskazane powyżej koncepcje ekwiwalencji dają się sprowadzić do podstawowego podziału na ekwiwalencję semantyczną i pragmatyczną. Podział taki wynika z podwójnego uwarunkowania przekładu. Jest on wtórny wobec oryginału i konieczne jest podporządkowanie na poziomie denotacji. Jednocześnie przekład funkcjonuje w nowej społeczności językowo-kulturowej i musi uwzględniać reakcje potencjalnych odbiorców. M. Mocarz zauważa, że: „Mimo istnienia tak wyraźnego podziału na ekwiwalencję semantyczną i pragmatyczną należy zaznaczyć, iż w praktyce oba te rodzaje nie są na tyle różne w swej istocie, by nie mogły współistnieć ze sobą. Badania przekładowe potwierdzają ścisłą korespondencję między nimi, czego namacalnym dowodem są próby połączenia wymienionych typów w jeden ogólny, jak to czynią kognitywiści, postrzegający ekwiwalencję jako cel procesu tłumaczenia na poziomie »obrazowania«, które należy rozumieć jako sposób użycia języka za pomocą dostępnych w repertuarze danego języka środków językowych dla przedstawienia określonych wycinków rzeczywistości” [Mocarz 2005, 90]. Ekwiwalencję, w zależności od przyjętego tertium comparationis, można osiągać na różnych poziomach. A. Bogusławski wyznaczył pięć poziomów osiągania ekwiwalencji przekładowej: poziom celu komunikacji, opisu sytuacji, informacji, ponadleksykalnych komponentów wypowiedzi oraz jednostek leksykalnych [zob. Bogusławski 1976, 301]. Podział ten jest bardzo bliski koncepcji poziomów ekwiwalencji, zaproponowanej przez W. Komissarowa, który wyszczególnił: „1) уровень языковых знаков, 2) уровень высказывания, 3) уровень сообщения, 4) уровень описания ситуации, 5) уровень цели коммуникации" [Komissarow 1973, 76].

Zadaniem ekwiwalencji formalno-estetycznej jest takie przekazanie przez tłumacza tekstu oryginału w języku przekładu, by TD (tekst docelowy) wywoływał taką samą lub najbardziej zbliżoną reakcję czytelnika przekładu jak TW (tekst wyjściowy) na czytelnika oryginału. Aby taki efekt 
osiągnąć, nie wystarczy ograniczyć się do wiernego przekładu leksyki. Należy też wziąć pod uwagę cały kontekst, który wymaga odpowiedniego stylu. Koller dodaje, że zastosowanie ekwiwalencji formalno-estetycznej w tekście przekładu oznacza, poza wykorzystaniem odpowiednich możliwości w celu ukształtowania tekstu, np. użycia odpowiednich form, konstrukcji gramatycznych, leksyki, ,analogię tworzenia” tekstu. Tłumacz powinien dążyć do zachowania rymu, rytmu i innych środków stylistycznych. Analizując ekwiwalencję formalno-estetyczną, Koller najwięcej uwagi poświęca metaforom i sposobom ich przekładu. Podaje on, że w języku istnieją trzy podstawowe typy metafor: zleksykalizowane, skonwencjonalizowane oraz okazjonalne [por. Koller 1995, 254]. Koller mówi także o trzech sposobach przekładu metafor. Sa to: „1. Übersetzung sensu stricto: das der AS-Metapher zugrunde liegende Bild ist in der ZS wiedergegeben. 2. Substitution: das der AS-Metapher zugrundeliegende Bild wird in der ZS durch ein anderes Bild ersetzt. 3. Paraphrase: die AS-Metapher wird nicht-metaphorisch übersetzt" [Koller 1995, 254].

W polskiej literaturze przedmiotu także wyróżnia się trzy podstawowe sposoby przekładu metafory:

„1. Przekład dosłowny, czyli zastąpienie metafory w tekście oryginalnym jej $»$ dosłownym « odpowiednikiem w tekście przekładu (...).

2. Reprodukcja, czyli zastąpienie metafory w tekście oryginalnym jakąś inną metaforą (...).

3. Zastąpienie metafory $\mathrm{w}$ tekście oryginalnym wyrażeniem niemetaforycznym" [Dąmbska-Prokop 2000, 130].

Każde słowo, określona aranżacja elementów tekstu, zawsze powodują albo zachowanie obrazu oryginału, albo jego zniekształcenie, zafałszowanie. Autentycznie twórcze dylematy narzucają się w tłumaczeniu wyrażeń, które komunikują sensy ukryte, informacje implikowane. Do takich wyrażeń należą tropy stylistyczne. W procesie ich translacji tłumacz poszukuje nie tyle ekwiwalentu słowa, co ekwiwalentu funkcji słowa. Każda decyzja tłumacza staje się decyzją twórczą [por. Balcerzan 1998, 144-150]. Specyficzna rola słowa i jego wpływ na kształt utworu poetyckiego determinuja pewne posunięcia translatorskie. Chwytem uprawionym w przekładzie jest naśladowanie języka oryginału na różnych poziomach. Naiwnością natomiast jest głoszenie ścisłego naśladownictwa jako jedynie dopuszczalnej formy przekładu. Dla współczesnego pojmowania przekładu poetyckiego podstawową zasadą jest „zasada ekwiwalencji funkcji” [por. Klemensiewicz 1955]. Posługując się wskazanymi wcześniej klasyfikacjami, dotyczącymi przekładu metafor, rozszerzając je jednocześnie na inne tropy, można zauważyć, że w analizowanym materiale przeważa tłumaczenie sensu stricte (przekład dosłowny) 
w stosunku do wszystkich zastosowanych tropów stylistycznych. Drugą co do liczebności grupę stanowi parafraza (detropizacja). Nieco rzadziej tłumacze zastosowali w tekście przekładu tropizację, czyli wprowadzenie tropu w miejsce jednostki nienacechowanej stylistycznie. Najsłabiej reprezentowana jest technika ostatnia - substytucja (reprodukcja), będąca przedmiotem analizy w danym artykule.

Reprodukcja, czyli zamiana tropu w tekście oryginału na inny trop w tekście przekładu, dotyczy tłumaczenia 25 jednostek, wyekscerpowanych spośród badanych 260 wierszy księdza Twardowskiego. Technika ta dotyczy przekładu różnych środków stylistycznych: epitetu, porównania, metafory, metonimii, animizacji, personifikacji, oksymoronu. Wprowadzone zmiany na poziomie jednostek języka są zazwyczaj wynikiem obranej strategii. Tłumacze dążą zarówno do zachowania norm języka docelowego, jak też zastosowania ekwiwalencji pragmatycznej na wyższych poziomach oraz utrzymania strony metrycznej i melodii wiersza. W analizowanych dwutekstach największą grupę (10 jednostek) stanowią porównania przetłumaczone na język rosyjski techniką reprodukcji. Wśród nich pięć porównań zostało przekazanych w języku docelowym z zastosowaniem epitetów w odnośnych fragmentach tekstów, np.:

(...) blawatek jak wianek/ nieustanny i krótki (...) („Do świętej Tereski", Zaufatem...)

(...) венчик василька/ неизменньй и недолговечный (...) („Святой Терезе", Х. Сурта, Стихи)

(...) jeszcze troche pomarudzi ostatnie stowo jak bezradny baran (...) (,Bez nas”, Zaufatem...)

(...) только вздрогнет последнее слово забытым барашком (...) („Без нас”, М. Осмоловская, Польская поэзия...)

Ten którego kochaja zostanie zbawiony/ choć kocha się dlatego że się nie rozumie/ niekiedy tylko ogarnia zdumienie/ jakby się księżyc świntuch rozebrat do naga (...) („Zbawiony”, Zaufatem...)

Тот кого любят будет спасен/ хоть любят оттого что ничего не понимают/ только охватит порой изумленье/ что месяи бесстылник раздет донага (...) („Будет спасен”, А. Базилевский, Cтuxu)

(...) Pan Jezus niewierzacych/ chodzi między nami/ czasami sie zatrzyma/ stoi jak krzyż twardy (...) („Pan Jezus niewierzących”, Zaufatem...) 
(...) Иисус неверующих/ ходит между нами/ но бьвает встанет/ крестом нерушимьим (...) („Иисус неверующих”, Х. Сурта, Стихи)

Cztery kolejne porównania, zawarte w tekstach wyjściowych, zostały przetłumaczone przy użyciu metafory w języku rosyjskim:

A pod glowa poduszka jak kwiaty/ a na oczach noc jak czarny puch (...) ( „Sen po czytaniu Biblii”, Zaufatem...)

(...) а под головой подушки чветок/ а на веках ночь словно черный nyx (...) ( „О жителях двух городов”, М. Осмоловская, Польская поэзия...)

(...) każdy odchodzi w swoja strone/ by serce nieść jak niecierpliwość/ czekać na jedna ważna chwile/ i kochać czego znieść nie sposób (...) ( „Po obu stronach”, Zaufałem...)

(...) уходят люди кто куда/ в сердиах уносят нетерпенье/ единственной минуты ждут/ и любят то же что клянут (...) („По обе стороны", А. Базилевский, Сделано в Польше)

Jeszcze nie umiesz być sam/ (...) jeszcze szukasz serca żeby je doić jak koze (...) („Jeszcze nie”, Zaufałem...)

Еще тыл не научился оставаться один на свете/ (...) еще подыскиваешь себе сердие для доенья (...) („Еще не”, С. Аверинцев, Сnеuume...)

Ryczat na cztery strony $\dot{z}$ e mitość odeszła/ miała być zawsze a była za krótko/ miała być jak mercedes a byta jak moskwicz (...) („Ryczal”, Zaufatem...)

Кричал на всех перекрестках что любовь ушла/ должна была быть вечной оказалась короткой/ должна была быть Мерседесом стала Москвичом (...) („Кричал”, А. Нехай, Сделано в Польwe)

W jednym przypadku porównanie, zaczerpnięte z tekstu polskiego, zostało zastąpione $\mathrm{w}$ języku przekładu personifikacją:

(...) księzyc jak rencista co wyszedt sie martwić (...) („Stwarzał”, Zaufatem...)

(...) пенсионер месяи вышел погрустить (...)” ( „Создал”, А. Базилевский, Польская поэзия...) 
Kolejną co do liczebności grupę (7 jednostek) stanowią wyrażenia metaforyczne, zastosowane przez Jana Twardowskiego, przetłumaczone na język rosyjski przy pomocy innych tropów stylistycznych. Wśród nich, w pięciu przypadkach, tłumacze zastosowali epitety, np.:

Jak daleko odszedteś/ (...) od pacierza/ od Polski z rana (...) ( „Rachunek dla dorosłego", Zaufałem...)

Как далеко ушел тьи / (...) от повторяемой молитвь/ от раненой Польши (...) („Счет для взрослого”, А. Нехай, Просьба)

Daj odejść od rzeczy okragłych zamieszanych uprzejmie kilka razy/ od tresury uśmiechu/ od rękawiczek rozdajacych kwiaty (...) („Odejść”, Zaufatem...)

Дай уйти от умеренного не в меру от всего что без углов округло/ от выдрессированной ульгбки/ от перчаток раздаюших розыл (...) („Уйти”, С. Аверинцев, Стихи)

Dwie następne metafory zostały przekazane w języku docelowym przy użyciu, odpowiednio: animizacji i personifikacji:

(...) wiatr zrywat matce kapelusz słomkowy/ jakby chciał przed matżeństwem jak kogut uciekać/ w wieczór co sie zapomniat i stat sie zielony (...) („Przychodzą same”, Zaufałem...)

(...) мамина соломенная шляпка/ как петушок отловленный на свадьбу/ взмьввала и рвалась навстречу ночи (...) („Встречи”, А. Гелескул, Польская поэзия...)

(...) wierzba $w$ fujarce smutna przy krowach wesota (...) („Gdyby”, Zaufatem...)

(...) ива плачет в свирели но возле коров веселеет (...) („Если бы”, А. Базилевский, Стихи)

Trzecia grupa (5 jednostek) to jednostki języka oryginału, wyrażone epitetami, którym w języku przekładu odpowiadają kolejno: porównania (2 jednostki), metafory (2 jednostki) oraz metonimia:

Świat zmaglowany/ polityka pudło (...) („Miłość”, Zaufałem...)

Мир как побитьй $/$ политика трепло (...) („Любовь”, Х. Сурта, Cneuume...) 
Patrze Jezus na brzegu/ wydawat sie tatwy/ taki do serca na co

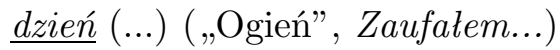

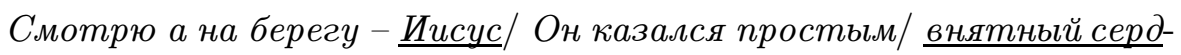
uу как истина каждого дня (...) („Огонь”, А. Базилевский, Сделано в Польше)

Że właśnie taki dzien, że właśnie takie dnie/ że wrogów petna sień, $\dot{z}$ cierń sie czarny pnie/ $\dot{z}$ e tuz za furta kwiat na piekne rzesy spadt/ maleńki, opuszczony, w powstaniu obtluczony (...) (***, Zaufałem...)

И только этот день, близнеи иного дня/ и вражеская чернь, и терние огня/ иветок, слетевший в ад без воли, наугад,/ в задумчивости, втайне, затерянный в восстанье (...) (***, Г. Ефремов, Польская поэзия...)

(...) W nocy letniej, petnej krużganków/ niemych Jerych, powalonych baszt (...) („Sen po czytaniu Biblii”, Zaufatem...)

(...) с летней ночью галереи слитьи/ башни тени ослепших нето-

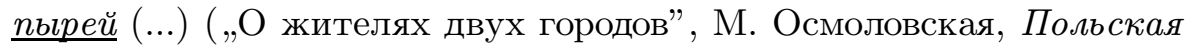
поэзия...)

(...) filozofowie mrucza na świętego Tomasza ustawionego już/ ze starymi rocznikami świetych - w archiwum raju (...) (***, Zaufałem...)

(...) философы недобрым словом поминают святого Фому/ сданного в райский архив/ вместе со старыми годовыми подшивками святых (...) (***, А. Базилевский, Сделано в Польше)

Kolejne dwa przypadki zastosowania techniki reprodukcji w procesie translacji to zastąpienie animizacji odpowiednio metaforą i epitetem w tekście docelowym:

(...) czemu tza opiekunka do gardta mi wpadta/ bo szczéscie sie urwato nie wiadomo po co (...) („O cokolwiek zapytasz”, Zaufatem...)

(...) почему слеза заступнииа жжет мне горло/ вырвано счастье из рук непонятно за ито (...) („О чем ни спросишь”, М. Осмоловская, Польская поэзия...)

To nieprawdziwe trudne nieudane/ ta radość pótidiotka bólu nowy kretyn/ żale jak byliny kwiaty zimnotrwate/ rozum co nie przeszkadza żadnemu odejściu (...) („To nieprawdziwe”, Zaufatem...) 
Все неладное тягостное подставное/ идиотская боль полоумная радость/ многолетней тоски зимостойкие всходы/ разум вечно беспомощный перед разлукой (...) („Все неладное”, А. Гелескул, Польская поэзия...)

W jednym przypadku jednostka oryginału, wyrażona personifikacją, została przetłumaczona przy użyciu epitetu:

(...) śnieq tak bardzo wzruszony że niewiele wiedziat (...) („To nieprawdziwe", Zaufatem...)

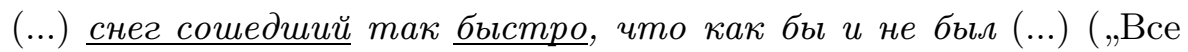
неладное", А. Гелескул, Польская поэзия...)

W badanym materiale znaleźć można także oksymoron, czyli epitet sprzeczny, zastosowany przez Jana Twardowskiego, oddany w języku rosyjskim za pomocą epitetu:

Gdzie sie prawda zaczyna a gdzie rozum kończy/ gdzie miłość między nami a gdzie już cierpienie/ czy tza czy na nosie ciepto zimnej wody/ dokad razem idziemy by umrzeć osobno (...) („Pytania”, Zaufałem...)

Где начинается правда и где кончается разум/ доколе меж нами любовь и с каких пор мученье/ слеза это или капля холодной водьи на носу/ куда мь движемся вместе итоб умереть в одиночку (...) („Вопросы”, А. Базилевский, Польская поэзия...)

Przytoczone przykłady pokazują, że analizowane tropy stylistyczne są często zindywidualizowane i ekspresywne, przekraczające pewne stereotypy literackie. Są one obliczone na wywołanie określonego nastroju i jednoznacznie określonych emocji. Przedstawiona analiza dwutekstów pokazuje, że tłumacze wykraczali poza utarte schematy językowe, by właściwie odczytać dodatkowe konotacje, odebrać komunikat zgodnie z intencją poety i z powodzeniem przekazać go w jezzyku docelowym. Wszystkie przedstawione powyżej zabiegi są środkiem do osiągnięcia ekwiwalencji formalno-estetycznej. Wiersz przekładu to, w dużej mierze, samodzielny, odrębny świat. Jest on związany z systemem form oryginału, ale tłumacz dokonuje w nim szeregu zmian. Dokonywany przez niego wybór form językowych, literackich, które najpełniej odpowiadają formom oryginału, w dużym stopniu decyduje o efekcie końcowym. Tłumacze wykazali się kreatywnością, zachowując często „autorską” postawę wobec oryginału. W ich decyzjach trudno dostrzec ślady strategii kolidującej z cechami stylistycznymi oryginału. Parametry 
tekstu wyjśsiowego zostają często przekazane w przekładzie za pośrednictwem różnych modyfikacji, które rekompensują ewentualne straty spowodowane różnicami językowymi i kulturowymi między tekstem oryginału i tekstem przekładu. Przekłady zawierają obrazy, ekwiwalentne w stosunku do tych, którymi posługiwał się autor.

\section{Źródła}

Twardowski J., 2007, Zaufatem drodze. Wiersze zebrane 1932-2006, Warszawa.

Астафьева Н., Британишский В., 2000, Польские поэты XX века. Антология, Ян Твардовский - перевод Н. Астафьевой, том 1, Санкт-Петербург.

Базилевский А., 2009, Сделано в Польше век XX, переводы Андрея Базилевского, Москва.

Твардовский Я., 1993, [w:] Польская поэзия XX век, под ред. А. Базилевского, переводы: М. Осмоловской, Г. Ефремова, А. Гелескула, А. Базилевского, С. Аверинцева, том 1, Москва, с. 77-138.

Твардовский Я., 2006, Стихи, переводы: С. Аверинцева, Н. Астафьевой, А. Базилевского, И. Баранова, О. Басий, Х. Сурты, Москва.

Твардовский Я., 2009, Спешите любить людей, переводы: С. Аверинцева, Н. Астафьевой, А. Базилевского, И. Баранова, О. Басий, А. Гелескула, М. Осмоловской, Х. Сурты, Москва.

Твардовский Я., 2010, Просъба, перевод с польского А. Нехая, Санкт-Петербург.

\section{Literatura}

Balcerzan E., 1998, Literatura z literatury (strategie ttumaczy), Seria: Studia o przekładzie, pod red. P. Fasta, Nr 6, Katowice.

Baluch J., 2007, Wiersz i przekład, Kraków.

Bogusławski A., 1976/1994, Problem tertium comparationis w porównaniu lingwistycznym, [w:] Bogusławski A., Sprawy stowa. Word Matters, Warszawa [Pierwodruk w roku 1976 w „Kwartalniku Neofilologicznym” z. 3, s. 295-303].

Ciesielska E., 2009, O języku i stylu poetyckim Jana Twardowskiego, Łódź.

Dąmbska-Prokop U., 2000, Mała encyklopedia przekładoznawstwa, Częstochowa.

Głowiński M., Sławiński J., Okopień-Sławińska A., 1967, Zarys teorii literatury, Warszawa. 
Jarosiński Z., 1985, Postacie poezji, Warszawa.

Jäger G., Müller D., 1982, Kommunikative und maximale Äquivalenz bei der Translation, „Übersetzungswissenschafftliche Beiträge” 5, Leipzig.

Klemensiewicz Z., 1955, Przektad jako zagadnienie językoznawstwa, [w:] O sztuce ttumaczenia, pod red. M. Rusinka, Wrocław, s. 85-97.

Koller W., 1983, Einführung in die Übersetzungswissenschaft, Heidelberg.

Koller W., 1995, The Concept of Equivalence and the Object of Translation Studies, Volium 7, Number 2, Target.

Kulawik A., 1997, Poetyka. Wstęp do teorii dzieła literackiego, Kraków.

Mocarz M., 2005, Predykatywy leksykalne w konfrontacji przektadowej (na materiale polskich przektadów prozy rosyjskiej XIX-XX w.), Lublin.

Nida E., Taber C., 1969, The Theory and Practice of Translation, Leiden.

Pajdzińska A., 1993, Frazeologizmy jako tworzywo wspótczesnej poezji, Lublin.

Pisarska A., Tomaszkiewicz T., 1996, Wspótczesne tendencje przekładoznawcze, cz. II, Poznań.

Pszczołowska L., 2002, Wiersz - Styl - Poetyka, Kraków.

Puzynina J., 2007, Ksiadz Jan Twardowski - poeta i człowiek, [w:] A to co na krótko może być na zawsze... Pokłosie spotkania poświęconego pamięci księdza Jana Twardowskiego, pod red. E. Hoffman-Piotrowskiej i J. Puzyniny, Warszawa, s. $15-29$.

Sochoń J., 2007, „Czy można serce zdjać naprawde z krzyża?” Wizja poezji wewnętrznie petnej księdza Jana Twardowskiego, [w:] A to co na krótko może być na zawsze... Pokłosie spotkania poświęconego pamięci księdza Jana Twardowskiego, pod red. naukową E. Hoffmann-Piotrowskiej i J. Puzyniny, Warszawa, s. 31-44.

Śliwińska A., 2009, Język polski: twórcy i ich dzieła, zestawienia i tabele, nauka o języku, wiedza o literaturze, Warszawa.

Tabakowska E., 1995, Gramatyka i obrazowanie. Wprowadzenie do językoznawstwa kognitywnego, Kraków.

Toury G., 1995, Descriptive Translation Studies and Beyond, Amsterdam - Philadelphia.

Wojciechowski J., 1999, Czytelnictwo, Kraków.

Wyderka B., 1995, Środki stylowe, [w:] Przewodnik po stylistyce polskiej, pod red. S. Gajdy, Opole, s. 53-181.

Комиссаров В., 1973, Слово о переводе, Москва. 
THE REPRODUCTION AS ONE OF WAYS ON YOU WILL ACHIEVE THE FORMAL-AESTHETIC EQUIVALENCE IN THE TRANSLATION (ON MATERIAL OF POEMS BY FATHER JAN TWARDOWSKI)

\section{S U M M A R Y}

The object of analysis are Jan Twardowski's poems translated into Russian in comparison with original texts. The aim was to check whether formal-aesthetic equivalence had been achieved in the translation of stylistictropes. The author presents their linguistic description and specific techniques, used by translators in the process of translation. As a result, the Russian texts of poems are aesthetically equivalent to the original texts.

Beata Dworakowska e-mail: beatadworakowska@wp.pl 